\title{
Efektivitas Penambahan Tepung Temulawak dalam Ransum sebagai Upaya Peningkatan Produktivitas Ayam Kampung Super
}

\author{
Effectivity of Adding Javanese Tumeric Powder in Feed to Increase Productivity of \\ Super Native Chicken
}

\author{
A. D. Anggraini, W. Widodo, I. D. Rahayu, A. Sutanto \\ Prodi Peternakan Fakultas Pertanian-Peternakan Universitas Muhamadiyah Malang \\ Jl. Raya Tlogomas No.246 Malang, Jawa Timur \\ Corresponding e-mail: apriliana@umm.ac.id
}

\begin{abstract}
This study was aimed to determine the effects of tumeric powder addition in diets on productivity of Super native chicken. The study was conducted for 65 days using 100 Super native chicken. The treatment diets were control basal diet (P1); P1 + 0.33\% tumeric powder addition (P2); P1 + 0.67\% tumeric powder addition (P3); P1 $+1 \%$ tumeric powder addition (P4). The data collected were analyzed by completely randomized design in oneway arrangement. Significant differences between treatments were further tested with Least Significance Different. Results of this study showed that the addition of tumeric powder in the diets did not affect feed intake, FCR and feed efficiency, but affect body weight gain, average body weight and income over feed cost (IOFC) of super native chicken. It could be concluded that tumeric powder can used in this study $0.33 \%$ in diets.
\end{abstract}

Key words: super native chicken, tumeric powder, productivity, IOFC

\begin{abstract}
ABSTRAK
Penelitian ini bertujuan untuk mengetahui pengaruh penambahan temulawak dalam pakan terhadap produktivitas ayam kampung super. Penelitian dilaksanakan selama 56 hari menggunakan 100 ekor ayam kampung super. Perlakuan yang diberikan berupa: pakan basal $\left(\mathrm{P}_{1}\right)$; P1 + temulawak 0,33\% $\left(\mathrm{P}_{2}\right)$; P1 + temulawak $0,67 \%\left(\mathrm{P}_{3}\right)$; $\mathrm{P} 1+$ lempuyang $1 \%\left(\mathrm{P}_{4}\right)$. Data yang diperoleh dianalisis variasi Rancangan Acak Lengkap pola searah. Perbedaan antar perlakuan diuji lanjut menggunakan uji Beda Nyata Terkecil. Hasil penelitian menunjukkan bahwa pemberian tepung temulawak tidak mempengaruhi nilai konsumsi pakan, FCR dan efisiensi pakan, namun mempengaruhi nilai pertambahan bobot badan harian, bobot panen ayam kampung super dan nilai income over feed cost (IOFC). Kesimpulan dari penelitian yang telah dilakukan bahwa tepung temulawak dapat diberikan pada pakan ayam kampung super sebanyak $0,33 \%$.
\end{abstract}

Kata kunci: Ayam kampung super, temulawak, produktivitas, IOFC

\section{PENDAHULUAN}

Ayam kampung super merupakan salah satu komoditas ternak penghasil daging yang digemari oleh masyarakat Indonesia. Hal tersebut dikarenakan ayam kampung mempunyai cita rasa daging yang berbeda. Sukmawati et al. (2015) menyebutkan bahwa daging ayam kampung super mempunyai rasa yang gurih dan enak. Keunggulan lain yang dimiliki oleh ayam kampung super adalah kemampuan beradaptasi yang baik terhadap kondisi lingkungan (Mubarak et al., 2018). Keunggulan yang dimiliki oleh ayam kampung super tersebut, perlu didukung agar dapat menghasilkan produk daging yang berkualitas. Peningkatan kualitas daging dapat diupayakan dengan cara memberikan pakan yang berkualitas dan memenuhi kebutuhan nutrien ternak.

Salah satu upaya yang dapat dilakukan adalah menambahkan feed additif kedalam pakan ayam kampung super. Temulawak merupakan salah satu bahan pakan yang dapat digunakan untuk ayam kampung super. Temuwalak (Curcuma xanthorriza Roxb) adalah salah satu tanaman obat yang mempunyai banyak khasiat. Beberapa literatur menunjukkan bahwa terdapat kandungan zat aktif di dalam temulawak. Rahardjo (2010) menyebutkan 
bahwa temulawak mempunyai banyak kandungan zat aktif yaitu xanthorrizol, kurkuminoid yang didalamnya terdapat zat kuning (kurkumin) dan desmetoxy kurkumin, minyak atsiri, protein, lemak, selulosa dan mineral. Kandungan zat aktif pada temulawak dapat merangsang dan mempengaruhi sekresi oleh pankreas sehingga dapat meningkatkan nafsu makan dan kontraksi usus (Aris et al., 2006). Penelitian lain yang dilakukan oleh Candra (2013) menyebutkan bahwa temulawak memiliki banyak manfaat antara lain sebagai antihepatitis, antikarsinogenik, antimikroba, antioksidan, antihiperlipidemia, antiviral, antiinflamasi, dan detoksikasi.

Penambahan temulawak dalam pakan ayam kampung super diharapkan dapat meningkatkan produktivitas ayam ampung super dengan membantu dalam proses penyerapan mikronutrien. Nutrien tersebut diharapkan dapat dimanfaatkan oleh tubuh ayam kampung super sehingga menunjang produktivitas yang optimal.

\section{MATERI DAN METODE}

\section{Ternak, Kandang, dan Instrumen}

Ternak yang digunakan pada penelitian ini adalah 100 ekor day old chick (DOC) Ayam Kampung Super dengan rataan bobot badan awal $42 \pm 4,1$ gram/ekor. Ayam Kampung Super dipelihara selama 56 hari. Kandang yang digunakan adalah kandang tertutup (closed house) yang terbagi dalam beberapa pen dengan kapasitas 5 ekor ayam setiap pen. Pakan perlakuan diberikan sejak hari pertama penelitian. Tepung temulawak yang digunakan adalah tepung temulawak komersil yang dijual dipasaran. Pemberian ransum sesuai kebutuhan dan air minum diberikan secara ad libitum. Pada saat penelitian ternak diberi vaksin diumur tertentu. Vaksin Newcastle Disease dan Infectious Bronchitis diberikan pada saat ternak berumur 4 hari, Vaksin Gumboro A diberikan pada umur 7 hari, Vaksin ND-IB pada umur 11 hari, Gumboro B pada umur 21 hari dan vaksin ND Clone pada umur 40 hari.

\section{Rancangan Penelitian}

Penelitian ini menggunakan analisis rancangan acak lengkap pola searah dengan menggunakan 4 perlakuan. Perbedaan antar perlakuan dilakukan uji lanjut menggunakan uji Beda Nyata Terkecil. Setiap kelompok perlakuan diberikan ulangan sebanyak 5 kali. masing-masing perlakuan terdiri dari 5 ekor ayam per pen replikasi. Perlakuan yang diberikan yaitu:

P1 = Pakan basal;

$\mathrm{P} 2=\mathrm{P} 1+0,33 \%$ tepung temulawak

$\mathrm{P} 3=\mathrm{P} 1+0,67 \%$ tepung temulawak

$\mathrm{P} 4=\mathrm{P} 1+1 \%$ tepung temulawak

\section{Parameter yang diamati}

Data variabel yang diamati pada parameter kinerja pertumbuhan adalah konsumsi pakan (feed intake; FI) dan konversi pakan (feed conversion ratio; FCR), efisiensi pakan (feed efficiency; $\mathrm{FE}$ ), pertambahan bobot badan harian (Daily gain; DG), bobot panen (Average body weight; $\mathrm{ABW}$ ) dan Income Over Feed Cost (IOFC). Perhitungan untuk mendapatkan data kinerja pertumbuhan ayam broiler adalah sebagai berikut :

Perhitungan 1.1 rumus untuk mendapatkan nilai feed intake

FI $=$ Pemberian pakan $(\mathrm{g})-$ Sisa Pakan $(\mathrm{g})$

Perhitungan 1.2 rumus untuk mendapatkan nilai daily gain

$\mathrm{DG}=\frac{\text { Rataan berat awal }(\mathrm{g})-\text { Rataan berat akhir }(\mathrm{g})}{\text { Lama pemeliharaan (hari) }}$

Perhitungan 1.3 rumus untuk mendapatkan nilai FCR

$$
\text { FCR }=\frac{\text { Konsumsi Pakan }}{\text { Pertambahan bobot badan }}
$$

Perhitungan 1.4 rumus untuk mendapatkan nilai feed efficiency

$$
\mathrm{FE}=\frac{\begin{array}{l}
\text { Pertambahan bobot } \\
\text { badan harian }
\end{array}}{\text { Konsumsi Pakan }} \times 100 \%
$$


Perhitungan 1.5 rumus untuk mendapatkan nilai IOFC

$\mathrm{IOFC}=(\mathrm{A} \times \mathrm{B})-(\mathrm{C} \times \mathrm{D})$

Keterangan :

$$
\begin{array}{ll}
\mathrm{A} & =\text { bobot badan akhir } \\
\mathrm{B} & =\text { harga jual ayam per } \mathrm{Kg} \\
\mathrm{C} & =\text { total konsumsi pakan } \\
\mathrm{D} & =\text { harga pakan perlakuan per } \mathrm{Kg}
\end{array}
$$

\section{HASIL DAN PEMBAHASAN}

Parameter kinerja pertumbuhan ayam kampung super yang diamati yaitu konsumsi pakan, FCR, pertambahan bobot badan harian, dan bobot panen ayam kampung super. Parameter yang diamati ditampilkan pada Tabel 1.

Tabel 1. Kinerja pertumbuhan ayam kampung super

\begin{tabular}{lccccc}
\hline \multirow{2}{*}{ Variabel } & \multicolumn{4}{c}{ Perlakuan } & P-Value \\
\cline { 2 - 6 } & $\mathrm{P} 1$ & $\mathrm{P} 2$ & $\mathrm{P} 3$ & $\mathrm{P} 4$ & \\
\hline FI (g/ekor/hari) & $43,49 \pm 2,04$ & $41,88 \pm 2,50$ & $39,60 \pm 4,64$ & $39,82 \pm 1,61$ & $\mathrm{P}>0,01$ \\
FCR & $3,02 \pm 0,16$ & $3,03 \pm 0,21$ & $3,11 \pm 0,44$ & $3,22 \pm 0,14$ & $\mathrm{P}>0,01$ \\
DG (g/ekor/hari) & $14,45 \pm 1,11$ & $13,83 \pm 0,24$ & $12,72 \pm 0,72$ & $12,21 \pm 0,70$ & $\mathrm{P}<0,01$ \\
ABW (g/ekor) & $853,67 \pm 62,72$ & $817,25 \pm 14,17$ & $755,13 \pm 40,00$ & $724,92 \pm 39,00$ & $\mathrm{P}<0,01$ \\
\hline
\end{tabular}

Keterangan $: \mathrm{FI}=$ Feed Intake $; \mathrm{FCR}=$ Feed Conversi Ratio; $\mathrm{DG}=$ daily gain; $\mathrm{ABW}=$ average body weight, $\mathrm{PI}=$ pakan basal; $\mathrm{P} 2=\mathrm{P} 1+0,33 \%$ tepung temulawak; $\mathrm{P} 3=\mathrm{P} 1+0,67 \%$ tepung temulawak; $\mathrm{P} 4=\mathrm{P} 1+$ $1 \%$ tepung temulawak.

Konsumsi Pakan Ayam Kampung Super

Hasil penelitian menunjukkan bahwa penggunaan tepung temulawak tidak mempengaruhi $(\mathrm{P}>0,01)$ konsumsi pakan ayam kampung super. Hasil penelitian menunjukkan bahwa rata-rata nilai konsumsi pakan ayam kampung antara 39-43 g/ekor/hari. Konsumsi pakan tersebut sejalan dengan penelitian oleh penelitian yang dilakukan oleh Widodo et al. (2017) dan Munira et al. (2016) yang menyebutkan bahwa rata-rata nilai konsumsi pakan ayam kampung super yaitu berkisar antara 42-44 $\mathrm{g} /$ ekor/hari. Peneliti lain Sukmawati et al. (2015) menyebutkan bahwa ayam kampung super yang diberi jus daun papaya terfermentasi dalam ransum komersial mempunyai nilai rata-rata berkisar antara 37,96-39,69 g/ekor/hari.

Pemberian tepung temulawak tidak mempengaruhi konsumsi pakan ayam kampung super tersebut dapat disebabkan karena kandungan nutrien pakan yang diberikan mempunyai nilai yang sama terhadap kebutuhan nutrisi. Sukmawati et al. (2015) menyebutkan bahwa ternak akan berhenti mengkonsumsi pakan apabila kebutuhan energi sudah tercukupi. Apabila kandungan energi pada pakan tidak mencukupi mkan kapasitas organ pencernaan merupakan salah satu pembatas terhadap nilai konsumsi pakan yang dihasilkan.
Hasil penelitian sejalan dengan Widodo et al. (2017) yang menyebutkan bahwa penggunaan lempuyang dalam pakan ayam kampung super yang menggunakan campuran jamu tidak mempengaruhi konsumsi pakan $(\mathrm{P}>0,05)$ pada keseluruhan umur. Wiryawan et al. (2005) juga menyebutkan bahwa penambahan kombinasi temulawak, jahe, dan bawang putih pada pakan tidak mempengaruhi konsumsi pakan ayam broiler strain Hubbard.

\section{Konversi Pakan Ayam Kampung Super}

Nilai konversi pakan merupakan salah satu indikator untuk melihat tingkat efisiensi penggunaan pakan. Nilai FCR yang semakin rendah menunjukkan bahwa jumlah konsumsi pakan yang dibutuhkan untuk menambah bobot badan (daging) juga semakin rendah dan semakin efisien penggunaan pakan tersebut. Hasil penelitian menunjukkan bahwa penggunaan tepung temulawak tidak mempengaruhi $(\mathrm{P}>0,01)$ konversi pakan ayam kampung super. Nilai FCR ayam kampung super pada penelitian menunjukkan nilai rata-rata 3,01 selama pemeliharaan.

\section{Pertambahan Bobot Badan Harian Ayam Kampung Super}

Penggunaan level tepung temulawak pada pakan mempengaruhi $(\mathrm{P}<0,01)$ pertambahan bobot badan harian ayam 
kampung super. Hasil penelitian menunjukkan bahwa nilai DG ayam kampung super yang paling tinggi pada P1 yaitu $14,45 \mathrm{~g}$ /hari dan nilai $\mathrm{DG}$ terendah pada $\mathrm{P} 4$ yaitu sebesar 12,21 . Hasil uji lanjut menunjukkan bahwa tidak ada perbedaan nyata nilai DG antara P1 dengan P2, P3 dengan P4. Namun, nilai DG pada P1 dan P2 berbeda dengan P3 dan P4. Selisih nilai DG yang didapatkan pada P1 dan P2 sebesar 0,62 g/ekor. Hasil tersebut menunjukkan bahwa perlakuan pemberian tepung temulawak 0,33 dapat memberikan nilai DG setara dengan P1.

\section{Bobot Panen Ayam Kampung Super}

Penggunaan level tepung temulawak pada pakan mempengaruhi $(\mathrm{P}<0,01)$ pertambahan bobot panen ayam kampung super. Nilai bobot badan tertinggi pada saat panen adalah P1 sebesar 853,67 g. Hasil uji lanjut menunjukan bahwa tidak ada perbedaan nyata nilai ABW antara P1 dengan P2 , P3 dengan P4. Namun, nilai ABW P1 dan P2 berbeda dengan P3 dan P4. Selisih nilai $A B W$ yang didapatkan pada $\mathrm{P} 1$ dan P2 sebesar 36,42 g/ekor.

Hasil penelitian pemberian tepung temulawak pada pakan ayam kampung super tidak memperbaiki nilai FI, FCR, dan FE namun mempengaruhi $\mathrm{DG}$ dan $\mathrm{ABW}$. Pemberian $0,33 \%$ (P2) tepung temulawak dapat memberikan nilai DG dan ABW setara dengan tanpa pemberian tepung temulawak (P1). Hasil tersebut menunjukkan bawah kandungan zat aktif di dalam temulawak dapat membantu untuk meningkatkan kinerja pertumbuhan ayam kampung super. Cahyono et al. (2011) menyebutkan bahwa terdapat 4 komponen kurkuminoid yang terdapat pada rimpang temulawak. Jumlah dari masingmasing komponen tersebut adalah 61-67\% kurkumin, 22-25\% demetoksikurkumin, 1$3 \%$ bisdemetoksi-kurkumin dan 10-11\% isomer kurkumin.

Kandungan kurkumin pada temulawak sebesar $22,3 \%$ melalui metode ekstraksi cair-cair satu kali sedangkan pada ekstraksi kedua diperoleh kadar kurkumin sebesar 30,4\% (Afif, 2006). Kandungan zat aktif lain yang terdapat pada temulawak adalah minyak atsiri. Kandungan minyak atsiri melalui penyulingan dalam ekstrak temulawak berkisar antara 14,99-33,03\% (Sembiring et al., 2006). Kandungan kurkumin dan minyak atsiri pada tepung temulawak dapat membantu merespon nafsu makan pada ternak. Hal ini karena temulawak dapat mempercepat kerja usus halus sehingga dapat mempercepat pengosongan lambung, dengan hal demikian akan timbul rasa lapar dan timbul nafsu makan (Wijayakusuma, 2003). Timbulnya nafsu makan akan meningkatkan konsumsi pakan dan menghasilkan pertambahan bobot badan yang tinggi.

\section{Efisiensi Pakan Ayam Kampung Super}

Parameter efisiensi pakan ayam kampung super dan Nilai IOFC yang diamati ditampilkan pada Tabel 2. Efisiensi pakan merupakan nilai yang diperoleh dari perbandingan antara pertambahan bobot badan dengan jumlah pakan yang dikonsumsi. Satuan nilai efisiensi menggunakan persen (\%). Nilai efisiensi pakan yang tinggi menunjukkan bahwa semakin efisien pemanfaatan nutrien pakan untuk pembentukan daging. Hasil pengamatan menunjukkan bahwa penggunaan tepung temulawak pada pakan tidak mempengaruhi $(\mathrm{P}>0,05)$ efisiensi pakan ayam kampung super. Nilai efisiensi pakan pada penelitian ini berkisar antara 31$33 \%$.

\section{Income Over Feed Cost Ayam Kampung Super}

Nilai IOFC merupakan hasil perhitungan yang digunakan untuk melihat seberapa besar penerimaan yang didapatkan setelah memelihara ayam kampung super. Nilai IOFC dihitung berdasarkan biaya pakan yang dikeluarkan selama pemeliharaan dan harga jual ayam kampung super pada saat panen. Banyaknya jumlah konsumsi pakan yang dikonsumsi oleh ternak pada saat pemeliharaan dapat mempengaruhi nilai IOFC yang diperoleh. Nurdiyanto et. al. (2015) menyebutkan bahwa peningkatan jumlah konsumsi ransum akan menyebabkan peningkatan biaya produksi ternak. 
Tabel 2. Efisiensi pakan dan nilai IOFC ayam kampung super

\begin{tabular}{lccccc}
\hline \multirow{2}{*}{ Variabel } & \multicolumn{5}{c}{ Perlakuan } \\
\cline { 2 - 5 } & $\mathrm{P} 1$ & $\mathrm{P} 2$ & $\mathrm{P} 3$ & $\mathrm{P} 4$ & \\
\hline FE (\%) & $33,21 \pm 1,75$ & $33,13 \pm 2,38$ & $32,37 \pm 2,83$ & $31,09 \pm 1,47$ & $\mathrm{P}>0,01$ \\
IOFC (Rp) & $15.209 \pm$ & $13.686 \pm$ & $12.057 \pm$ & $10.194 \pm$ & $\mathrm{P}<0,01$ \\
& 1475,45 & 971,58 & 1547,25 & 1009,17 & \\
\hline
\end{tabular}

Keterangan $: \mathrm{FE}=$ feed efficiancy; $\mathrm{IOFC}=$ Income Over Feed Cost; $\overline{\mathrm{PI}}=$ pakan basal; $\mathrm{P} 2=\mathrm{P} 1+0,33 \%$ tepung temulawak; $\mathrm{P} 3=\mathrm{P} 1+0,67 \%$ tepung temulawak; $\mathrm{P} 4=\mathrm{P} 1+1 \%$ tepung temulawak.

Penggunaan tepung temulawak pada pakan ayam kampung super mempengaruhi nilai IOFC $(\mathrm{P}<0,01)$ yang diperoleh selama pemeliharaan. Hasil pengamatan menunjukkan bahwa nilai IOFC tertinggi diperoleh pada P0 yaitu sebesar Rp 15.209,00 dan nilai terendah diperoleh pada P4 sebesar Rp 10.194,00. Tingginya nilai IOFC yang dihasilkan menunjukkan bahwa penerimaan yang didapat dari hasil penjualan ternak juga semakin tinggi (Rasyaf, 2011). Hasil uji lanjut menunjukkan bahwa P4 mempunyai nilai IOFC yang berbeda dengan P1, P2, dan P3. Nilai IOFC P2 sama dengan $\mathrm{P} 3$ dan $\mathrm{P} 1$, namun nilai IOFC yang dihasilkan P3 berbeda dengan nilai IOFC P1.

Hasil uji lanjut menunjukkan bahwa nilai IOFC pada P1 tidak berbeda dengan P2. Apabila dilihat dari nilai IOFC dan produktivitas, penggunaan tepung temulawak sebanyak $0,33 \%$ dapat diberikan pada pakan ayam kampung super. Apabila jumlah pemberian tepung temulawak pada pakan semakin meningkat dapat menyebabkan nilai IOFC semakin rendah.

\section{KESIMPULAN}

Kesimpulan pada penelitian ini yaitu level terbaik penambahan tepung temulawak sebesar 0,33 persen dalam ransum ayam kampung Super.

\section{DAFTAR PUSTAKA}

Afif, K.H. 2006. Peningkatan kadar kurakumin ekstrak etanol temulawak dengan metode ekstraksi cair-cair. Skripsi.https://repository.ipb.ac.id/bit stream/handle/12345678 9/48355/G06kha.pdf?sequence $=1 \&$ is Allowed $=\mathrm{y}$
Aris, S., E. Mirwandhono, dan Emmyliam. 2006. Pemanfaatan tepung temulawak (Curcuma xanthorriza Roxb) dan molases dalam ransum terhadap performa dan income over feed cost (IOFC) Itik Peking umur 156 hari. Jurnal Agribisnis Peternakan. 2(2) : 67-71.

Cahyono, B., M.D.K. Huda, L. Limantara. 2011. Pengaruh pengeringan rimpang temulawak (Curcuma xanthorriza Roxb) terhadap Kandungan dan komposisi kurkuminoid. Reaktor. 13 (3) : 165-171.

Candra, A. A., 2013. Aktivitas hepatoprotektor temulawak pada ayam yang diinduksi pemberian parasetamol. Jurnal Penelitia Pertanian Terapan. 13 (2) : 137-143.

Mubarak, P. R., L. D. Mahfudz, dan D. Sunarti. 2018. Pengaruh pemberian probiotik pada level protein pakan berbeda terhadap perlemakan ayam kampung. Jurnal Sain Peternakan Indonesia. 13(4) : 357- 36

Munira, S., L.O. Nafiu., A. M. Tasse. 2016. Performans ayam kampung super pada pakan yang disubtitusi dedak padi fermentasi dengan fermentor berbeda. JITRO. 3 (2): 21-29.

Nurdiyanto, R., R. Sutrisna, dan K. Nova. 2015. Pengaruh ransum dengan persentase serat kasar yang berbeda terhadap performa ayam jantan tipe medium umur 3-8 minggu. Jurnal Ilmiah Peternakan Terpadu. 3 (2) : 12-19. 
Rahardjo, M. 2010. Penerapan SOP budidaya untuk mendukung temulawak sebagai bahan baku obat potensial. Perspektif. 9 (2) : 78-93.

Rasyaf, M. 2011. Panduan Beternak Ayam Pedaging. Cetakan IV. Penebar Swadaya Jakarta.

Sembiring, B. B., Ma'mun, dan E. I. Ginting. 2006. Pengaruh kehalusan bahan dan lama ekstraksi terhadap mutu ekstrak temulawak (Curcuma xanthorriza Roxb). Buletin Penelitian Tanaman Rempah dan Obat. 17(2) : 53-58.

Sukmawati, N. M.S., I.P. Sampurna, M. Wirapartha, N.W. Siti, dan I.N. Ardika. 2015. Penampilan dan komposisi fisik karkas ayam kampung yang diberi jus daun pepaya terfermentasi dalam ransum komersial. Majalah Ilmiah Peternakan. 18 (2) : 39-43

Widodo, W., I. D. Rahayu., A. Sutanto., A. D. Anggraini. 2017. Penambahan lempuyang dalam pakan ayam kampung super yang menggunakan campuran jamu. Prosiding Seminar Nasional dan Gelar Produk 2. Hal: 469-473.

Wijayakusuma, H. 2003. Penyembuhan dengan Temulawak. Jakarta: Milenia Populer.

Wiryawan, K.G., S. Suharti, dan M. Bintang. 2005. Kajian antibakteri temulawak, jahe, dan bawang putih terhadap Salmonella typhimurium serta pengaruh bawang putih terhadap performans dan respon imun ayam pedaging. Media Peternakan. 28 (2): $52-62$. 